\title{
Internationalization and Knowledge Management Strategies of Service Firms: Impact of Regulatory Environment in Regional Markets
}

\author{
Christopher Findlay, Hussain Gulzar Rammal*, Elizabeth L. Rose, Vijay Pereira
}

*Corresponding Author

Accepted for publication in Journal of Knowledge Management on 27 October 2021 https://doi.org/10.1108/JKM-06-2021-0425

\begin{abstract}
:
Purpose: We study the influence and impact of regulations and highlight the barriers to market entry faced by Australian professional service firms in the European Union (EU) and their strategies to manage and transfer tacit knowledge.

Design/methodology/approach: We collected data by reviewing relevant regulatory documents and conducting semi-structured interviews with key informants from Australian architecture firms and senior representatives from the professional, trade, and regulatory bodies in Australia and Europe.

Findings: Historically, Australian professional service firms use the United Kingdom (UK) as their EU base. The mutual recognition of qualifications and prior experiences are barriers to intra-organizational expatriation and knowledge transfer. The study identifies the dual nationality of the architects as a way of circumventing the residency/nationality restrictions. Originality: The study discusses Brexit and how the uncertainty surrounding the UK and EU's services' agreement adds to the complexity for non-European firms' market entry and operations in the region.
\end{abstract}

Keywords: knowledge management, trade in services, Australia, European Union, professional services, Brexit. 


\section{INTRODUCTION}

The literature on internationalization has evolved, moving from a discussion about the incremental approach of traditional multinational enterprises (MNEs) to the rapid internationalization of born global firms (Brockman, Dow, Phan, Rammal and Zurbruegg 2021). The contemporary understanding of how firms internationalize in regional and global markets has been developed primarily on insights from the manufacturing sector (Meyer, Skaggs, Nair and Cohen 2015) However, the internationalization process and strategies of service firms have been largely ignored. By their very nature, service firms rely on the transfer of knowledge within their organizational network to achieve competitive advantage (Ashok, Narula and Martinez-Noya 2016, Ganguly, Talukdar and Chatterjee 2019, Garrick and Chan 2017). The transfer can be particularly challenging across national boundaries due to institutional differences (Guo, Jasovska, Rammal and Rose 2020) or the disseminative and absorptive capacity of the knowledge sources and recipients (Mehreen, Rammal, Pereira and Del Giudice 2021).

Previous studies have focused on the internal capabilities of the firms when selecting the appropriate entry mode and ignored the influence of the regulatory and institutional environments in the decision-making (Asakawa, Ito, Rose and Westney 2013). For professional services firms, the internal capabilities are embedded in their human capital, or simply put, the tacit knowledge held by individuals in the firm. Unlike explicit knowledge, which can be transferred through written instructions and shared documents, the management and cross-border transfer of tacit knowledge requires interpersonal interaction (Patel, Rammal, Ferreira and Prikshat 2021). Hence, the movement of professionals to share existing and learning new knowledge is critical for service firms to sustain their competitive advantage. However, there are several challenges that firms face in this process. 
The international supply of services remains highly regulated, with national governments, professional bodies, and supranational organizations such as the World Trade Organization's (WTO) General Agreement on Trade in Service (GATS) playing an important role in determining what foreign firms can offer services in a member state's territory and how. Firms face another layer of complex regulatory issues when internationalizing into a regional market with several countries having distinct entry requirements (Arregle, Miller, Hitt and Beamish 2016). The International Business (IB) literature has paid scant attention to these regulatory barriers and how they influence international service firms' internationalization process and operations.

In this study, we address these critical regulatory and contextual challenges internationalizing service firms face and explore how they influence the entry modes used by professional service firms and how they operationalize their international activities. Thus, we answer the following research question:

What formal and informal regulatory factors influence the internationalization and knowledge management processes and strategies of professional service firms from nonmember states into regional markets?

To investigate these regulatory issues, we study the internationalization process of Australian architecture service firms, emphasizing their market entry and knowledge management strategies employed in the European Union (EU). Australia and countries in the EU, notably the United Kingdom (UK), have a long history of cultural and economic ties. Therefore, this study of Australian architecture firms' operations in the EU provides the opportunity to explore how the regulatory environment in a regional market, the notion of psychic and geographic distances in the internationalization process, and the influence of the formal and informal regulatory requirements, include the GATS modes of supply, influence 
the decision of firms to select a particular country for market entry. The study also explores how Brexit will potentially affect firms' operations from non-member states like Australia that have historically focused on the UK as their base within the European market.

\section{INTERNATIONALIZATION AND KNOWLEDGE MANAGEMENT IN SERVICES FIRMS}

Services represent the dominant economic sector, accounting for 65 percent of global Gross Domestic Product (GDP: 2019 estimate) (World Bank 2019) and approximately 51 percent of employment in the world (2019 estimate). In 2019, cross-border trade in services represented 13.5 percent of the world's total GDP (World Bank 2020). Despite the importance of services to the global economy, the sector has remained mostly underresearched in the IB literature (see for example, Kundu and Lahiri 2015, Rammal and Rose 2014), and there is a need for more studies to address this phenomenon of services firms' internationalization.

Historically, international services were limited in scope due to the belief that the production and consumption of services could not be separated and consequently could not be exported. However, advancements in ICT have allowed cross-border delivery of services. As a result, it is possible to decouple production and consumption of certain services and classify them as hard or soft services (Blomstermo, Sharma and Sallis 2006). Services that can be decoupled and exported, such as architectural services, engineering design, and packaged software, are categorized as hard services. Other services such as healthcare and hospitality, where production and consumption cannot be separated, are soft services. While foreign market entry behavior in industries dominated by hard services appears to be like firms in the manufacturing sector, soft-service industries are restricted in the set of entry modes 
available to them, such as licensing, franchising, and FDI. In addition, the option of contractual entry modes for soft services can create complex ownership structures due to collaboration and cooperation across borders (Ball, Lindsay and Rose 2008, Pla-Barber, Sanchez-Peinado and Madhok 2010).

Contemporary issues covered in the international services research include the learning capabilities of the firms and reputation (Borda, Newburry, Teegen, Montero, NájeraSánchez, Forcadell, Lama and Quispe 2017), customer experience (Segal-Horn and Dean 2009), the performance of the firms (Bello, Radulovich, Javalgi and Schrer 2015, Zhang, Zhong and Makino 2015), value creation (Jensen and Petersen 2014), the form of market entry (Grönroos 2016), control (Boussebaa 2015), reshoring (Albertoni, Elia, Massini and Piscitello 2017), organizational structure (Breunig, Kvålshaugen and Hydle 2014), services embeddedness (Jack, As-Saber and Edwards 2015), institutional complexity (Faulconbridge and Muzio 2016), and theorizing of the internationalization process (Cort, Griffith and White 2007). Despite the increasing number of studies on the global service firm, the influence of the regulatory environment and informal barriers on internationalization and market entry strategies remains under-researched. Also, how these regulations impact international knowledge transfer and the strategic response of firms also requires further investigation (Ferreira, Mueller and Papa 2020, Ruiz-Pava and Forero-Pineda 2020)

Countries that are members of the World Trade Organization (WTO) have made commitments related to modes of cross-border supply of services under the GATS (Czinkota 2006, Meyer et al. 2015). These commitments determine the level of openness for foreign service providers, in particular service sectors and the sub-sectors (Rammal and Rose 2014). The four modes of supply recognized under the GATS are: 
- Mode 1: Cross-border supply - covers services provided via telephone or electronically without the provider or the consumer leaving their home territory. This mode includes services such as offshore technical support.

- Mode 2: Consumption abroad - relevant mode for services where the consumer travels to the service provider's country. Services such as tourism and education tend to use this mode of supply.

- Mode 3: Commercial Presence - includes supply activities that require a physical presence in the territory of the consumer. This includes representative office, subsidiary, joint venture, and licensing or franchising.

- Mode 4: Movement of natural persons - This mode covers the movement of professionals from one territory to another to undertake business activities. This includes all forms of expatriation, including fly-in-fly-out activities (Konan and Maskus 2006, Mattoo 2003).

In this study, we investigate how formal and informal regulations influence architecture firms' internationalization and knowledge transfer processes. We use the GATS (1991) categorization of services, where architecture services are classified as professional services, a sub-sector of business services. Professional services tend to be multimodal, regularly using all four modes of supply (Drake-Brockman and Findlay 2011). However, Mode 4 remains a critical option for firms to transfer knowledge through individuals and explains the large number of expatriate options employed by MNEs to facilitate this process.

Extant literature acknowledges the importance of physical interaction between expatriates and host-country nationals to facilitate tacit knowledge transfer (Guo, Rammal, Benson, Zhu and Dowling 2018), which is described as the 'socialization' process (Nonaka and Von Krogh 2009). However, many of these studies tend to treat the choice of expatriation as a 
strategy that MNEs can employ independently and fail to acknowledge influences such as the GATS's Mode 4 commitments made by countries to facilitate or restrict the ability of expatriates to enter and work in their territory. Hence, this study contributes to the literature by addressing this gap and studying how the regulations influence the knowledge management processes of service MNEs. In doing so, we attempt to highlight the knowledge transfer strategies that firms employ in response to these regulatory barriers.

\section{AUSTRALIA-EU ECONOMIC RELATIONS}

Australia has historical, cultural, trade, and economic ties with countries in the European Union. According to the 2016 census, more than 65 percent of the Australian population had European ancestry (ABS 2017). In 2008, Australia and the EU signed a Partnership Framework, covering economic and political relations between the two. The Treaty of Lisbon, which came into force on 1 December 2009, resulted in a new institutional structure within the EU. The Australian government has defined terms of engaging with the EU regarding the new structure (Markovic 2012). Since early 2012, Australia and the EU have been negotiating a formal framework agreement that includes many economic and trade cooperation provisions (European Commission 2012). In 2018, the two sides commenced negotiations for a comprehensive free trade agreement (FTA) (European Commission 2018). After the UK's exit from the European Union in 2021, Australia and the UK began discussing a bilateral free trade agreement between the countries (DFAT 2021).

Australia's exports to the EU include coal, pharmaceutical products (excluding medicaments), gold and legal tender coins, and oil-seeds and oleaginous fruits, whereas the major imports from the EU include medicaments, passenger motor vehicles, pharmaceutical products, and civil engineering equipment and parts. The total trade in goods between the 
two amounted to A \$58.7 billion in 2019-2020 (Department of Foreign Affairs and Trade 2021). In 2019, Australia was ranked as the $14^{\text {th }}$ largest export destination and the $35^{\text {th }}$ largest import source for the EU (Department of Foreign Affairs and Trade 2021).

\section{Services Sector in Australia:}

Australia's total trade in services in 2018-19 was worth A $\$ 198.7$ billion, accounting for 22.3 percent of the country's total trade in goods and services (Department of Foreign Affairs and Trade 2020). In two-way trade in services, the United States is the largest trading partner, accounting for 13.9 percent (A $\$ 27.67$ billion) of total services trade, followed by China (11.1 percent; A $\$ 21.97$ billion) and the United Kingdom (7.7 percent; A \$15.23 billion $)^{1}$ (Department of Foreign Affairs and Trade 2020). The data on services published by the Australian Services Roundtable classifies architecture under the "Architectural, engineering and other technical services" sector. In 2018-19, the sector exports were worth A $\$ 97.12$ billion, of which the architectural services were worth $\mathrm{A} \$ 55$ million. Total imports of the sector in 2018-19 totaled $\mathrm{A} \$ 101.59$ billion, and architectural services were worth A \$39 million (Department of Foreign Affairs and Trade 2020).

The trade in services between Australia and the EU represents 18.9 percent of Australia's total services trade (Department of Foreign Affairs and Trade 2020). The major services exported to the EU include professional, technical and other business services, and personal travel excluding education. The major services imported from the EU included personal travel excluding education and transport services.

Services Sector in Europe:

\footnotetext{
${ }^{1}$ These figures are for trade with individual countries and do not include trade with regional blocs.
} 
The architecture sector contributes $€ 17$ billion to Europe's economy, with 560,000 architects registered in the region. The largest construction markets in Europe consist of Germany, the UK, France, Italy, and Spain (Architects' Council of Europe 2021). The provision of services across the 28 economies in the EU requires coordination and uniformity in applying rules and regulations. The Services Directive adopted by the European Parliament in December 2006 attempts to achieve a level of uniformity across the EU (European Communities 2007). The Directive requires the Member States to simplify procedures and formalities concerning establishing a business within their territory and the cross-border provision of services. Member States are also required to set up "points of single contact", where service providers can obtain all relevant information and complete all the formalities electronically (European Communities 2007). The Architecture services sector was covered under this Directive, with a stated aim to eliminate barriers such as nationality/residency requirements, territorial restrictions, or the minimum number of employees (European Communities 2007).

While some studies have explored the trade relations between Australia and Europe (see for example Rafferty and Ham 2004), the topic of trade in services between Australia and the EU has remained largely unexplored.

\section{RESEARCH METHOD}

We apply the qualitative phenomenological research design to investigate the internationalization process of Australian professional service firms and the influence of the regulatory environment on the firms' market entry strategy in the EU. As highlighted earlier, the internationalization of services firms has mostly been ignored or accepted to follow the same patterns as those of manufacturing firms without relevant investigation. We 
deemed phenomenology suitable for this explorative research design, as it allows the identification of inherent knowledge and seeks true meaning within the research as identified by the researcher and the respondent in a combined interpretive response to data (Groenewald 2004). Using the concepts of psychic distance, geographic distance, and liability of outsidership from the Uppsala model and the formal and informal rules from institutional theory, we attempt to explain the barriers to knowledge transfer and the strategies Australian service firms employ.

\section{Data Collection and Analysis}

Having identified the formal barriers to entry using the commitments made under the GATS agreement by Australia and the EU, we wanted to explore the informal regulations that influence the internationalization process and entry strategies of professional service firms. To achieve this, we sought insights from experienced individuals from various organizations, and therefore, the qualitative phenomenology study using data collected via interviews was selected for this research (Hycner 1999).

We followed the information-oriented strategy and selected three Australian architecture firms with operations in the EU as the critical cases for this study (Flyvbjerg 2006). According to Flyvbjerg (2006), critical cases allow researchers to collect information that facilitates logical deductions to be made that would apply to other cases. The firms were identified after discussion with a representative from the Australian architectural professional association, and the criteria for their selection included their international experience and presence in the EU market. Initial contact with these firms was made through email in which the project's scope and purpose were detailed, and subsequently, interviews were organized. To ensure the anonymity of these firms, the three cases are 
identified as 'Company A' 'Company B' and 'Company C' in this paper. Information about the three case companies is provided in Table 1.

\section{INSERT TABLE 1 HERE}

To ensure that we captured different perspectives on the phenomenon under investigation, we used a combination of interviews, analysis of the regulatory agreements (GATS), and relevant documents published by the architectural professional associations and the trade departments in Australia and Europe as the source for our data. In addition, we conducted interviews with key informants from the three architectural firms, senior officials from the professional association representing architects in Australia and Europe, senior managers of the Australian and European services associations, and an officer from the Australian trade department in Brussels. The profile of the interviews is provided in Table 2.

INSERT TABLE 2 HERE

Semi-structured interviews were conducted as this allowed us to ask both open and closedended questions (Glesne 1999). The interviews were held in the Australian cities of Adelaide, Canberra, and Melbourne, and in the European cities of Brussels and London, with each interview on average lasting for one hour. Interviewing the key informants from the companies and the regulatory bodies meant that detailed information about the organizations' operations and the regulatory environment in the EU was obtained. The interviewees from the architecture firms were asked questions about the company's 
establishment, their initial internationalization, their international experience and current operations, the entry mode(s) used to initially enter the EU, their current mode(s) of supply in the EU, the regulatory environment, and operational issues in EU.

The key informants from the government agencies and professional bodies were asked questions related to the regulatory environment in the EU, with particular attention to the modes of supply permitted within the EU, the movement of people, and the recognition of qualification and experience of architects.

The interviews were audio-recorded and then transcribed verbatim. The interviewees were emailed a copy of the transcripts to ensure that there were no factual errors. We also availed of this opportunity to ask further questions or seek clarification on issues identified during the transcription (Seymour 2006). Repeat interviews were conducted in person and onphone with 3 of the interviewees to seek responses to further questions raised during data collection after the initial interviews were conducted.

We analyzed regulatory and trade documents published by the WTO, the GATS, and the relevant professional, trade, and investment bodies in Australia and the EU. The collection of data using various methods such as interviews, observations, and documentation allowed for methodological triangulation, which increased the credibility and validity of the results (Ashok, Al Badi Al Dhaheri, Madan and Dzandu 2021, Denzin 2006). We undertook a thematic analysis of our interview data and content analysis of the published regulations. The analysis of the interviews and the documentation identified elements such as 'nature of work'. 'competition', 'entry mode', 'networks', 'renovation', 'education', 'prior experience', 'local presence', 'safety', and 'movement of architects'. These codes were then accumulated under categories and repeated to the point where the categories stabilized, and 
no further themes or patterns could be found in the data (Silverman 2000). Three themes emerged from the data analysis stage, which is presented in the findings section.

\section{FINDINGS}

We first summarize the GATS mode of supply commitments made by Australia and the EU, followed by the findings from the interview data. Generally, the commitments made in the architectural services show a favorable environment for foreign firms in both Australia and the EU. Australia has no limitations on Market Access or National Treatment for Modes 1, 2, and 3. Only Mode 4 is unbound, which suggests that there are no firm commitments to limit the movement of professionals (WTO and the World Bank 2018). The EU, while generally open, is a bit more complex due to the regional nature of the market. There are no restrictions on Mode 1 of supply, except for countries like Belgium, Greece, Italy, and Portugal, which are unbound.

Similarly, Modes 2 and 3 are generally free. However, mode 4 limitations are identified in Denmark, Netherlands, United Kingdom, and Spain, where a University degree and professional qualifications and three years of professional experience in the sector is required (WTO and the World Bank 2018). Estonia also requires that the national authorities recognize academic and professional qualifications and the license be delivered by the Professional Association (WTO and the World Bank 2018).

The three themes identified in the data analysis process are presented as our key findings: Nature of work in the EU; Market Entry Strategy, and Mutual Recognition and Movement of Professionals.

\section{Nature of Work in the EU:}


The nature of architecture work undertaken in Australia and the EU and the way work is allocated in the EU were identified as a vital issue by the interviewees from the companies. Australia is a young country, and much of the work undertaken is in designing for new buildings. In contrast, historically, in the EU, much of the work relates to the refurbishment of old buildings. Most of the renovation work in the EU tends to be undertaken by the original architects and construction firms. The interviewees explained that this difference in the nature of work undertaken and the lack of prior experience of Australian architecture firms limits their opportunity to win work in the European market:

As architects, we build predominately new in Australia. And as architects in Asia, we also build new. But in Europe, you build essentially old with a lot of refurbishments and a lot of regeneration of buildings. Their new work is, by comparison, relatively limited and tightly held - Interviewee CB.

Despite this limitation, the companies identified the expansion of the EU and the recent entry of member states such as Poland to be an opportunity for Australian architects to take advantage of rapid infrastructure development and construction to gain a foothold in the region.

Architectural services are classified as hard services and can be decoupled and exported. This would suggest that firms could undertake the architecture services in the headquarters and transfer the design to the clients electronically (covered under the GATS' Mode 1 of supply). However, the three Australian architecture firms we studied all had a physical presence in the region. The company representatives we interviewed explained that a significant amount of work in Europe was won through participation in design competitions. These competitions were only open to architecture firms that were registered in the host territory. In order to be invited to bid for the competition, firms need to demonstrate that they are reputable in the provision of quality service. Such a reputation in the local 
community can only be developed if the firm has a physical presence in Europe. For Australian firms, entering such competitions is a learning process on bidding for the work being offered. Australian firms 'have a good reputation in the industry in EU' (Interviewee $\mathrm{CC})$, but they lack the local knowledge about competitions. In contrast, firms from the EU specialize in such competitions:

The European market, in a sense, is so often dominated by competition.....there are firms in Europe that do nothing but enter competitions, and that is how they run a business. There would be 15-20 people out there ...doing competitions, and they get paid well even when they don't win and come second or third-Interviewee CB.

Many non-EU firms, including some Australian, have successfully won these competitions or got recognized for their bids. However, while the competitions are seemingly open to all, it is a requirement that not only should the firms have a presence in Europe, they are also required to be registered with the relevant professional and regulatory body:

The way we go about things is to go into competitions, it is a great way to win really interesting, good, high-profile work and a great way to get known. The European Union publishes all the projects that are coming up, and our [local EU] office is registered with them, so we can apply to enter competitions or submit for projects Interviewee CA.

So, while there seem to be no formal barriers to the provision of architecture services in the region, the local presence requirement excludes design ideas from firms operating outside of the EU.

\section{Market Entry Strategy:}

The internationalization literature suggests that firms commence international expansion by first entering markets in close geographic proximity and have low psychic distance.

Australia provides a unique country setting where the geographic proximity is with Asia, but it shares historical and cultural links with Western European countries in terms of psychic 
distance. The three case companies in this study commenced their internationalization process by entering the Asian market. However, the entry into the Asian markets was due to the familiarity with the nature of work of building new in the region's emerging economies. Companies $\mathrm{A}$ and $\mathrm{C}$ made their first foray into the international market by entering the Hong Kong market, while Company B entered the Thai and Malaysian markets.

The entry of the companies into the EU has been recent, with all three having entered the market in the last two decades. The firms entered the region by establishing a local office in the UK to service the EU market. The interviewees from the companies explained that the cultural and language similarities between Australia and the UK were the main reason for selecting the market for entry. In addition, the familiarity with the legal system in the UK meant that the companies could reduce the uncertainty associated with entering the EU:
"We picked London because of language and law. We had a great sense of comfort in the British law of contracts [and] the standards were what we normally deal with architecturally. It was very adaptable” - Interviewee CB.

For Company B, an office in London also appealed to the firm's client base in the Middle East and North America that was interested in investing in the UK. The local office in the UK provided an opportunity for the client to invest in the market and work with the Australian architects they previously had experience with:
"We recognize that there are many of our clients out of the Middle East and out of North America investing in [the UK], and looking into bargains especially in London. It wasn't that we didn't like [other EU countries], but some of our client base in the Middle East was strongly related and integrated into London either through education or property ownership, so that was another [reason] to go to London" - Interviewee CB.

In other instances, the presence in Europe provided the opportunity to extend operations into markets outside of the region. For example, Company A expanded its operations in Europe 
and opened an office in Warsaw, Poland. The office in Warsaw was credited with creating business links and networks in Eastern Europe, and this was seen as a reason why the firm managed to secure business in Russia. Company $\mathrm{C}$ was the newest entrant of all three firms in the EU and established offices in London and Cardiff.

Although they differed in the form used, the three firms used equity-based FDI (covered under the GATS' Mode 3 of supply). Company A and C entered the market by opening a new office in London, while Company B entered the market by acquiring an existing practice in London. The entry mode used by Company A and C was consistent with the company's preferred strategy of keeping fiscal and design controls by internalizing the operations. However, Company B did not have a preferred strategy and selected the acquisition strategy as it was seen as a sound opportunity and good timing to enter the market. Interviewee CB explained that previously they had worked with a small Londonbased architecture firm, which was struggling to keep their operations afloat. Company B saw this as an opportunity to take control over the operations and to exploit the currency exchange rate advantage they enjoyed at the time. The firm believed that they could undertake their work in the UK at nearly a third of the cost in those days and proceeded to acquire the London-based organization.

When asked about possible regulatory barriers to entry in the markets they have established a presence in, the interviewees explained that they first identified the issues in the market and then chose the appropriate mode of supply. The decision to service the market was based on the firms' internal abilities and the market conditions:

"The Singapore market is very tightly held, so we are in there in the design area. In China, the establishment costs are very high, and WOFE [Wholly-Owned Foreign Enterprise] is difficult" Interviewee $\mathrm{CC}$. 
Addressing the barriers to entry was a secondary concern as firms would "try and secure a project and [then] work out how to service it" - Interviewee CA. The interviewees did not highlight any specific host-region regulations that affected the firm's operations concerning the EU. However, they did identify some country-level regulations that influenced their choice of the UK as the regional base in the EU:

"We looked at France, and we thought that was highly regulated, quite restrictive, and we didn't like the idea of people only working 36 hours or a figure like 32 hours, it didn't fit our model at all" Interviewee CB.

Other issues identified as limitations in the EU included the emphasis on using the local language for business in Germany and the lack of appropriate infrastructure and supporting industries in some member states that have recently joined the regional economic union.

\section{Mutual Recognition and Movement of Professionals:}

The regulatory environment in the EU was seen as stable and protective of firms' operation in the economic union. All the company interviewees acknowledged that firms operating in the EU did not have to concern themselves with loss of intellectual property and ideas, which was raised by them when discussing their operations in some countries in Asia.

Of the regulatory issues facing Australian firms in the EU, the mutual recognition of qualification and prior experience was identified as the main barriers. Interviewee PA-EU explained that although there was an automatic recognition system in place after implementing the EU Services Directive, architects were still required to register individually. The formal requirements suggest that if the architect had a relevant diploma (or in some member state territory like the UK, a university degree), and a minimum of three years post-diploma experience, they could register to practice in Europe. However, in 
practice, the recognition of the qualification was undertaken by the professional association in the EU.

Interviewee PA-A explained that they were aware of Australian architects with years of experience being informed that their degrees from Australian universities were deemed insufficient and were asked to gain a further post-registration experience (up to 7 years) in Europe before the individual could receive a license. Interviewee PA-EU elaborated on this issue and explained that local knowledge about building techniques could not be easily transferred. Therefore, architects needed to live the relevant experience in Europe before they are permitted to work. However, Australia did not have such specific requirements for international firms entering the market, and the services sector was described as being open and competitive (Interviewee SA-A). In addition, the Australian government's commitments under the GATS show no limitations on Market Access or National Treatment for Modes 1 , 2, and 3 in Architectural Services and no specific qualification or experience requirements for Mode 4 of supply.

Australian architects face issues in recognition of their prior qualifications and experience. While the "services directive and the Mutual Recognition of Professional Qualifications allow architects to move easily and operate across the territories of member states" (Interviewee SA-EU), Australian educational qualifications are not necessarily accepted as being equivalent to the EU requirements, and this creates further hurdles for Australian professionals. Interviewee PA-A explained that this was a concern for Australian trained architects even though "historically many Australian architecture students and graduates went to Europe to get work experience”.

The lack of clarity over the mutual recognition issues was a significant concern for the companies as it affected their ability to undertake work in the EU. Interviewee TD-A 
explained that the Australian trade department's office in Brussels was available to help Australian firms to work through the various formal and informal barriers. However, the companies expressed ignorance over their presence and support, with Interviewee CC stating that even though their practice has been established and operating in London for a while, they had "not received any previous communication or information about commercial support from the Australian government in the EU”.

The three companies identified the intra-organizational transfer of knowledge from headquarters to the international subsidiary as a critical resource. This transfer is accomplished in two ways: either through work being transferred electronically to the headquarters (Mode 1) or through the movement of employees as expatriates. Interviewee CB elaborated by giving the example of the firm's presence in the Middle Eastern region, which allowed them to access opportunities for new work. However, the designs were all made in the headquarters in Australia, using the Mode 1 form of supply. In the case of the EU, some of the member countries have not committed to this Modal form of supply and remain unbound. Since Mode 1 supply is not assured and the lack of mutual recognition impedes expatriation, Australian architecture practices have few choices other than to hire local EU architects. While efforts were being made in the EU to attract more professionals from outside Europe through the issuance of the Blue Card (a temporary residency and work permit for skilled professionals), the interviewees believed that there would be few opportunities to use the scheme as there is no shortage of locally qualified architects currently registered in Europe:

"We are in the process of issuing Blue Cards, which are equivalent to the Green Cards issued by the United States. While these cards are for temporary stay initially, the individuals will eventually have the option of staying long-term. But agreeing on who should get the Blue Card will not be easy" Interviewee PA-EU. 
Interviewees PA-EU and SA-EU explained that these operational realities in the EU are not intended to be a barrier but rather a means of ensuring that the work undertaken in the EU is of good quality and the safety of the population is not compromised. The interviewees also explained that if no proper checks and balances were in place, then the completion of projects could also be delayed. Both interviewees referred to the example of the infrastructure development for the European Football Cup, which was held in Poland and Ukraine in 2012. The Polish government put a call for bids for constructing highways, and a Chinese firm was successful as its bid to construct a part of the A2 motorway at a price that was much lower than that of the second bidder. However, the Chinese company was unable to deliver due to issues relating to the payment of sub-contractors and other quality issues. The government was then forced to find another bidder to complete the task. The interviewees explained that the registration and local residency requirements were in place to avoid similar issues in other sectors, including services.

Australian firms, however, have attempted to respond to what they consider to be informal barriers in the EU. One of the key strategies has been the use of dual-nationals to manage the operations in Europe. As highlighted earlier, a large section of the Australian population has European ancestry, and many of these are eligible to hold dual-citizenship (for example, Australian and British). If a company had such individuals in the headquarters, they could still achieve their objective of intra-organizational knowledge transfer by using their existing staff to manage operations in a boundary-spanning role. This was the case with Company C's manager:

"I was based in the Australian office. Then one day, we were asked if any of us were eligible for European residency. I checked and found that because of my mother being British, I was eligible for British 
residency. We applied for the appropriate documentation, and that is

how I came to lead the team in London" Interviewee CC.

\section{DISCUSSION}

The findings of this study highlight the formal and informal regulatory issues that international professional service firms face in the EU. We find that the formal commitments made by the EU in the architectural services sector under the GATS do not pose many barriers for the entry of international firms. However, informal barriers influence the entry mode and knowledge transfer abilities of professional service firms.

The EU market for architecture places emphasis on design competitions. These competitions are seen as prestigious, and winning the awards can lead to future business opportunities in the EU. However, these competitions require a local presence as they are only open to architecture firms registered in the EU. Hence, while there are no restrictions on the mode of supply under the GATS commitments, firms offering services under Mode 1 - cross-border supply, would be unable to participate in the design competitions. Furthermore, there are diverging views on the competition system in the EU. Some of the interviewees commented that the competitions provide a good opportunity for Australian firms to engage with other firms in the industry and the regulatory body, providing an impetus for future business growth in the EU market. Others commented that these competitions gave the local EU firms an advantage, as some design firms specialize in winning competitions only and then outsourcing the job to other architecture firms. Hence, the competitions can reward organizations that are best at filling out detailed documentation and understand the way the awards are made, rather than those that can provide the best design. However, we found that Australian architecture firms have learned from their local presence and experience in the EU market over time and have recently been successful in winning many such competitions. 
We found that the Australian firms' initial international move was into countries in the East Asian region concerning the market entry strategy. Only after some international experience was gained in the Asian market did these firms enter the EU. On the face of it, this finding suggests that the notion of psychic distance did not matter for Australian service firms, and the firms tend to enter geographically close markets. However, further investigation of this pattern reveals that Australian service firms make their first international foray into markets where the work available matches their experience and is similar to the work undertaken at home.

Australia is a relatively new country, where much of the industrialization and economic growth has occurred in the last century. Much of the work for architects and construction companies has been in constructing new buildings, with little work related to the restoration or refurbishment of old buildings. Similarly, the economies in Asia were on the path of rapid economic growth in the 1980s and had many opportunities to construct new buildings. The experience of Australian firms in undertaking such work allowed them to successfully bid for and build these new structures. In contrast, the EU market has many old historical buildings, and work related to restoring these buildings is usually allotted to the original architects. For new buildings in the EU, the allocation of work was influenced by how firms performed in the design competitions. With a lack of international knowledge and experience, Australian firms held back from entering the EU market until they gained sufficient international exposure. Hence, in terms of patterns of internationalization, our study has revealed that Australian architecture firms internationalize by entering markets in close geographic proximity where the nature of work was similar to that at home, and over time as their experience increases, they enter markets that are geographically distant but have a low psychic distance. 
The three firms that we studied entered the EU market by establishing an office in London. The reasons for selecting the UK as the entry point into the EU market included language, cultural and historical ties, and familiarity with the legal system. Hence, while the initial internationalization was undertaken in regions where the nature of work was similar, once the firms decided to enter the EU market, they chose the UK as the base due to the low psychic distance it has from Australia. This finding is consistent with the study of Rafferty and Ham (2004), who identified the UK as the most significant recipient of Australia's FDI into Europe. All three firms in our study chose the equity mode for entering the market (Mode 3 supply under the GATS classification). The selection of this supply mode was influenced by the company's desire to internalize its operations in the EU and the rules related to local presence and competition in the EU market.

The companies' internationalization process also revealed that historically, an active presence in the UK helped serve the EU market and was also seen as a base for serving the larger European market and the Middle East. The interviewees explained that several of their clients in the Middle East had links to the UK, where they had received higher education. It was due to these links the clients in the Middle East wanted to invest in the UK. Having an office in the UK meant that they could coordinate with their clients in the Middle East and carry out their work. The firms also highlighted the networked nature of work, and we found that opportunities for expansion into Poland, Russia, and Greece had come about due to the firms' presence and networks in the EU. This finding supports the notion of "liability of outsidership", as suggested in the updated Uppsala model in 2009 (Johanson and Vahlne 2009).

Finally, our findings highlight the role of the professional associations in influencing the movement of non-EU professionals in the territory. The professional architectural 
association undertakes the issue of mutual recognition of qualification and experience in the EU. The commitments made by the EU under the GATS state that a relevant diploma and three-years post-diploma experience is required to qualify and practice as an architect in the region. However, in practice, the recognition of educational qualification and previous experience in the sector discriminates against those architects who have qualifications and experience from outside the EU. The professional architecture association and regulatory bodies in the EU claim that this interpretation of the GATS commitment was not enforced to discriminate against non-EU architects, but rather an effort to ensure that individuals entering the EU market have sufficient experience, skills, and knowledge about the EU market. This finding shows how the professional association protects the interests of its members and influences the regulatory environment and the enforcement of the commitments made by the government (Greenwood, Suddaby and Hinings 2002).

For Australian architecture firms, the restriction on the movement of professionals can limit their ability to transfer knowledge within their organizational network. Hitt, Bierman, Uhlenbruck and Shimizu (2006) stated that for professional services firms, the most important resource is the knowledge held by their personnel. The inability to mutually recognize the qualification and experience of Australian and EU architects in each other's territory means that firms are unable to use their principal resources and are forced to use locally trained architects. Our finding suggests that some Australian firms respond to this residency requirement by using dual-nationals who work in their Australian offices and transfer the knowledge and know-how to the EU office. Previous studies have looked at the issue of biculturals and dual-citizen workforces that live in two or more cultures and can adjust to the host country's business culture. However, our study shows that Australian architecture firms do not select dual-nationals for their cultural knowledge, and they are chosen merely to meet the residency requirement. Figure 1 illustrates the formal and 
informal barriers Australian architecture firms face and their strategic response to these barriers.

\section{INSERT FIGURE 1 HERE}

\section{CONCLUSION AND FUTURE STUDIES}

The findings of the study highlight several knowledge-sharing strategies employed by service firms when faced with barriers. From the internationalization theory perspective, we find that service firms test the application of their existing knowledge by entering markets where the nature of work is similar to that at home. This allows them to gain international experience and knowledge about how international markets operate. This finding extends the internationalization literature that states that firms will enter low psychic or geographic distance markets. One could argue that Australian firms entering markets in Asia is due to geographic proximity. However, as the interviewees explain, many countries in Asia, like Australia, are building new structures and Australian firms have the required knowledge and expertise to take advantage of it.

Once they gain the required experience and knowledge about international markets, they move to other markets where the nature of work also includes refurbishments. So, while the element of internationalization based on experience does ring true, the choice of markets is based on the knowledge and skills of the service firms. The entry into regional markets like Europe helps Australian service firms further build their knowledge about refurbishment 
work, extend their network, and find new opportunities in large regional markets, especially when the home market is relatively small.

The study also has implications for the formal and informal institutional aspects and the socialization element of knowledge management. Our study highlights that organizations need to consider the formal and informal barriers, including the mutual recognition of qualifications and experience, as potential challenges when deciding on expatriation as an option in the international market. As highlighted in the literature, the use of expatriates allows the transfer of knowledge across national boundaries. However, the informal barriers can restrict the ability of the professionals to undertake relevant activities in the host country. As a result, some Australian firms seek out dual-nationals in the organization to avoid such barriers in the host country. This is a unique strategy that the organizations use to facilitate socialization and the transfer of tacit knowledge and can be used in conjunction with inpatriation strategy (Guo et al. 2020) where firms may not have dual-nationals at the home office.

With Great Britain no longer part of the EU (referred to more commonly as Brexit), it is questionable whether this pattern of Australian firms entering the EU via the UK would be followed in the future. The Brexit discussions between the EU and the British government rarely emphasized outcomes for the services sector, adding to the uncertainty faced by service providers in the UK (Hill 2021). Borchert (2016) suggests that once outside the EU, then UK-based firms will face a deterioration of market access conditions that varies across modes and countries. Australia is planning for such eventualities for their firms and has commenced negotiations with the EU for a comprehensive free trade agreement that will cover both goods and services (European Commission 2018). Kerneis (2018) suggests that a future trade agreement involving professional services between Australia and the EU could 
follow the FTA between Canada and the EU. The mutual recognition of qualification and experience was devolved to the professional bodies. Australian service firms that already have a presence in Europe have the advantage of having built networks in the wider EU area and are relocating or opening new offices.

The UK and Australia are negotiating a bilateral free trade agreement after Brexit (Crowe 2018). Winters (2018) observed that restrictions remain on access to professional services markets in the UK and that Brexit might allow Australia to ask for more liberal treatment there. Some initial agreements between the two sides include mutual recognition of professional qualification, which address one of the barriers Australian service firms previously faced (Tillett 2021). The future market entry strategy of Australian firms will be influenced by the outcomes of these current and planned future negotiations.

The study has limitations that may guide future research. The findings of the study are based on data collected from three Australian architecture service firms. Future studies could test the internationalization pattern found in this study in other service sectors and other territories. Other studies could also explore the role of dual-nationals and business networks in the internationalization process, as found in our study. Finally, we discuss the market entry and knowledge transfer strategies but do not compare the operations of the Australian and EU service firms. A comparison of their operations could be a topic of further investigation.

Our study provides rich insights into the internationalization process and entry modes used by services firms and the influence of regulations on the operations of such firms. The findings of this study have implications for services firms, policymakers, and professional industry bodies. For firms, the implications relate to the patterns of internationalization and the influence of regulations on selecting personnel in the host market. The study highlights 
issues related to mutual recognition of qualification and prior experience of professionals. There is an opportunity for industry, professional associations, and regulatory bodies to work together to find ways to strengthen and clarify the formal qualification process for architects. This would require a rethink of the accreditation of diplomas and other educational qualifications and how the sector governs itself and self-assesses the expertise and competence of the professionals. 
Table 1: Description of the Companies

\begin{tabular}{|c|c|c|c|}
\hline & Company A & Company B & Company $C$ \\
\hline Year of Establishment & 1972 & 1904 & 1938 \\
\hline Year of Internationalization & 1979 & 1992 & 1991 \\
\hline $\begin{array}{l}\text { International Office } \\
\text { Network }\end{array}$ & $\begin{array}{l}\text { London, Manchester, } \\
\text { Jakarta }\end{array}$ & $\begin{array}{l}\text { Bangkok, Kuala Lumpur, } \\
\text { Hong Kong, London, Los } \\
\text { Angeles, New York, San } \\
\text { Francisco, Beijing, } \\
\text { Shanghai, Abu Dhabi, } \\
\text { Dubai }\end{array}$ & $\begin{array}{l}\text { Hong Kong, China } \\
\text { (multiple locations), } \\
\text { Thailand, Singapore, } \\
\text { London, Cardiff }\end{array}$ \\
\hline International Experience & $\begin{array}{l}\text { Asia, EU, Middle East, } \\
\text { Russia, Caribbean }\end{array}$ & $\begin{array}{l}\text { Asia, EU, USA, Turkey, } \\
\text { Russia }\end{array}$ & Middle East, Asia, EU \\
\hline
\end{tabular}

Table 2: Profile of interviewees

\begin{tabular}{|c|c|c|}
\hline $\begin{array}{l}\text { Interviewee } \\
\text { Code }\end{array}$ & Position in Organization & $\begin{array}{l}\text { Location of } \\
\text { Interview }\end{array}$ \\
\hline $\mathrm{CA}$ & Director of Administration, Company A & $\begin{array}{l}\text { Melbourne, } \\
\text { Australia }\end{array}$ \\
\hline $\mathrm{CB}$ & $\begin{array}{l}\text { Managing Director of Operations, Company } \\
\text { B }\end{array}$ & $\begin{array}{l}\text { Melbourne, } \\
\text { Australia }\end{array}$ \\
\hline $\mathrm{CC}$ & Head of Architects, Company C & $\begin{array}{l}\text { London, United } \\
\text { Kingdom }\end{array}$ \\
\hline PA-EU & $\begin{array}{l}\text { Senior Official of European Architecture } \\
\text { Professional Association }\end{array}$ & Brussels, Belgium \\
\hline SA-EU & $\begin{array}{l}\text { Senior Manager of European Services } \\
\text { Association }\end{array}$ & Brussels, Belgium \\
\hline PA-A & $\begin{array}{l}\text { Senior Official of Australian Architecture } \\
\text { Professional Association }\end{array}$ & Adelaide, Australia \\
\hline SA-A & $\begin{array}{l}\text { Senior Manager of Australian Services } \\
\text { Association }\end{array}$ & Canberra, Australia \\
\hline TD-A & $\begin{array}{l}\text { Officer from the Australian Trade } \\
\text { Department in the EU }\end{array}$ & Brussels, Belgium \\
\hline
\end{tabular}




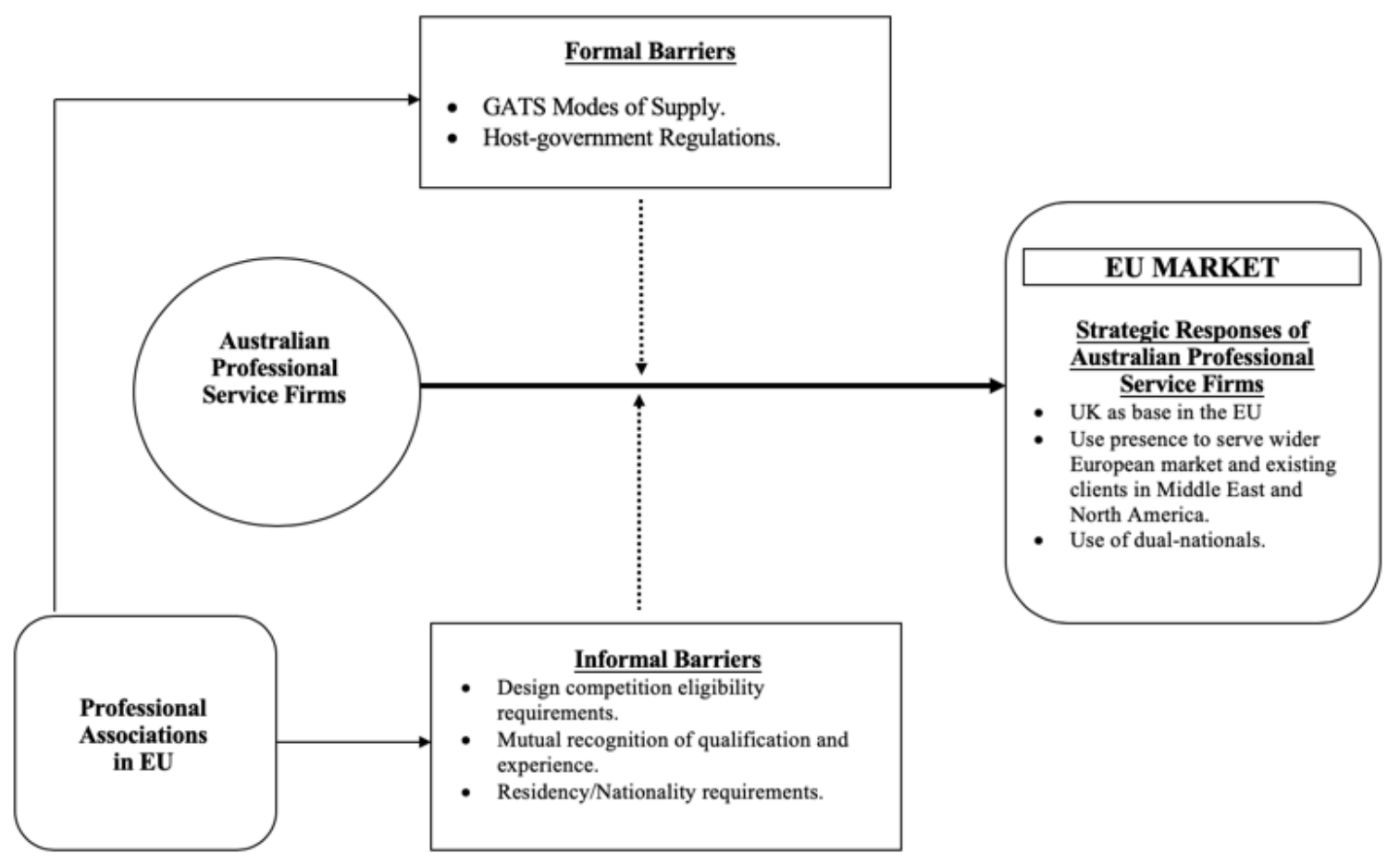

Figure 1: Barriers and Strategic responses of Australian professional service firms in the EU 


\section{REFERENCES}

ABS. (2017), "Census of Population and Housing: Australia Revealed, 2016", available at: http://www.abs.gov.au/ausstats/abs@.nsf/Latestproducts/2024.0Main\%20Features22016 (accessed 4 July 2018).

Albertoni, F., Elia, S., Massini, S. and Piscitello, L. (2017), "The reshoring of business services: Reaction to failure or persistent strategy?", Journal of World Business, Vol. 52 No. 3, pp. 417-30.

Architects' Council of Europe. (2021), The Architectural Profession in Europe 2020: A Sector Study, Mirza \& Nancey Research Ltd for The Architects' Council of Europe., Brussels. https://euagenda.eu/upload/publications/2020acesectorstudy.pdf.

Arregle, J., Miller, T., Hitt, M. and Beamish, P. (2016), "How does regional institutional complexity affect MNE internationalization?", Journal of International Business Studies, Vol. 47 No. 6, pp. 697-722.

Asakawa, K., Ito, K., Rose, E.L. and Westney, D.E. (2013), "Internationalization in Japan's service industries", Asia Pacific Journal of Management, Vol. 30 No. 4, pp. 1155-68.

Ashok, M., Al Badi Al Dhaheri, M.S.M., Madan, R. and Dzandu, M.D. (2021), "How to counter organisational inertia to enable knowledge management practices adoption in public sector organisations", Journal of Knowledge Management, Vol. ahead-of-print.

https://doi.org/10.1108/JKM-09-2020-0700.

Ashok, M., Narula, R. and Martinez-Noya, A. (2016), "How do collaboration and investments in knowledge management affect process innovation in services?", Journal of Knowledge Management, Vol. 20 No. 5, pp. 1004-24.

Ball, D.A., Lindsay, V.J. and Rose, E.L. (2008), "Rethinking the paradigm of service internationalisation: Less resource-intensive market entry modes for information-intensive soft services", Management International Review, Vol. 48 No. 4, pp. 413-31.

Bello, D.C., Radulovich, L.P., Javalgi, R.G. and Schrer, R.F. (2015), "Performance of professional service firms from emerging markets: Role of innovative services and firm capabilities", Journal of World Business, Vol. 51, pp. 413-24.

Blomstermo, A., Sharma, D.D. and Sallis, J. (2006), "Choice of Foreign Market Entry Mode in Service Firms", International Marketing Review, Vol. 23 No. 2, pp. 211-29.

Borchert, I. (2016), "Services Trade in the UK: What Is at Stake?", UK Trade Policy Observatory, Vol. Briefing Paper 6.

Borda, A., Newburry, W., Teegen, H., Montero, A., Nájera-Sánchez, J.J., Forcadell, F., Lama, N. and Quispe, Z. (2017), "Looking for a service opening: Building reputation by leveraging international activities and host country context", Journal of World Business, Vol. 52 No. 4, pp. 503-17.

Boussebaa, M. (2015), "Control in the multinational enterprise: The polycentric case of global professional service firms", Journal of World Business, Vol. 50 No. 4, pp. 696-703. Breunig, K.J., Kvålshaugen, R. and Hydle, K.M. (2014), "Knowing your boundaries: Integration opportunities in international professional service firms", Journal of World Business, Vol. 49 No. 4, pp. 502-11.

Brockman, P., Dow, D., Phan, H.L., Rammal, H.G. and Zurbruegg, R. (2021), "Young aspiring globals (YAGs): early-stage strategies of knowledge-focused international entrepreneurs", Journal of Knowledge Management, Vol. ahead-of-print https://doi.org/10.1108/JKM-05-2021-0375. 
Cort, K.T., Griffith, D.A. and White, D.S. (2007), "An attribution theory approach for understanding the internationalization of professional service firms", International Marketing Review, Vol. 24 No. 1, pp. 9-25.

Crowe, D. (2018), "Australian meeting clears way for UK trade deal after Brexit", The Sydney Morning Herald, Vol. 12 April.

Czinkota, M.R. (2006), "Academic freedom for all in higher education: The role of the general agreement on trade in services", Journal of World Business, Vol. 41 No. 2, pp. 14960.

Denzin, N. (2006), Sociological Methods: A Sourcebook, 5th ed., Aldine Transactions, Chicago.

Department of Foreign Affairs and Trade. (2020), Trade in Services Australia 2018-19, DFAT, Canberra.

Department of Foreign Affairs and Trade. (2021), "European Union", available at: https://dfat.gov.au/trade/resources/Documents/eu.pdf (accessed 22 May 2021).

DFAT. (2021), "Australia-UK FTA benefits fact sheet", available at:

https://www.dfat.gov.au/trade/agreements/negotiations/aukfta/benefits (accessed 3 August 2021).

Drake-Brockman, J. and Findlay, C. (2011), "Waiting till the cows come home: New routes to service reform", East Asia Forum, Vol.

http://www.eastasiaforum.org/2011/01/24/waiting-till-the-cows-come-home-new-routes-toservices-reform/.

European Commission. (2012), "Countries and Regions: Australia", available at: http://ec.europa.eu/trade/creating-opportunities/bilateral-relations/countries/australia/ (accessed 3 November 2012).

European Commission. (2018), "Towards an EU-Australia Trade Agreement", available at: http://ec.europa.eu/trade/policy/in-focus/eu-australia-trade-agreement/ (accessed 18 August 2018).

European Communities. (2007), Handbook on the Implementation of Services Directive, European Commission, Luxembourg.

Faulconbridge, J. and Muzio, D. (2016), "Global Professional Service Firms and the Challenge of Institutional Complexity: 'Field Relocation' as a Response Strategy", Journal of Management Studies, Vol. 53 No. 1, pp. 89-124.

Ferreira, J., Mueller, J. and Papa, A. (2020), "Strategic knowledge management: theory, practice and future challenges", Journal of Knowledge Management, Vol. 24 No. 2, pp. 12126.

Flyvbjerg, B. (2006), "Five Misunderstandings about Case-Study Research", Qualitative Inquiry, Vol. 12 No. 2, pp. 219-45.

Ganguly, A., Talukdar, A. and Chatterjee, D. (2019), "Evaluating the role of social capital, tacit knowledge sharing, knowledge quality and reciprocity in determining innovation capability of an organization", Journal of Knowledge Management, Vol. 23 No. 6, pp. 110535.

Garrick, J. and Chan, A. (2017), "Knowledge management and professional experience: the uneasy dynamics between tacit knowledge and performativity in organizations", Journal of Knowledge Management, Vol. 21 No. 4, pp. 872-84.

GATS. (1991), "Services Sectoral Classification List", available at: www.wto.org/english/tratop_e/serv_e/mtn_gns_w_120_e.doc (accessed 10 September 2012).

Glesne, C. (1999), Becoming Qualitative Researchers: An Introduction, 2nd ed., Addison Wesley Longman, USA. 
Greenwood, R., Suddaby, R. and Hinings, C.R. (2002), "Theorizing change: the role of professional associations in the transformation of institutionalized fields", Academy of Management Journal, Vol. 45 No. 1, pp. 58-80.

Groenewald, T. (2004), "A phenomenological research design illustrated", International Journal of Qualitative Methods, Vol. 3 No. 1, pp.

http://www.ualberta.ca/ iiqm/backissues/3_1/pdf/groenewald.pdf.

Grönroos, C. (2016), "Internationalization strategies for services: a retrospective", Journal of Services Marketing, Vol. 30 No. 2, pp. 129-32.

Guo, Y., Jasovska, P., Rammal, H.G. and Rose, E.L. (2020), "Global mobility of professionals and the transfer of tacit knowledge in multinational service firms", Journal of Knowledge Management, Vol. 24 No. 3, pp. 553-67.

Guo, Y., Rammal, H.G., Benson, J., Zhu, Y. and Dowling, P.J. (2018), "Interpersonal relations in China: Expatriates' perspective on the development and use of guanxi", International Business Review, Vol. 27 No. 2, pp. 455-64.

Hill, A. (2021), "UK's services sector starts to count the real cost of Brexit", Financial Times, Vol. 10 May No. https://www.ft.com/content/d0c10195-0e2e-4913-af743b7057163e3f.

Hitt, M.A., Bierman, L., Uhlenbruck, K. and Shimizu, K. (2006), "The importance of resources in the Internationalization of Professional Service Firms: The good, the bad, and the ugly", Academy of Management Journal, Vol. 49 No. 6, pp. 1137-57.

Hycner, R.H. (1999), "Some guidelines for the phenomenological analysis of interview data", in Bryman, A. and Burgess, R. (Eds.), Qualitative Research, Sage Publications, London, South Africa, pp. 143-64.

Jack, R., As-Saber, S. and Edwards, R. (2015), "Service embeddedness and its role in a firm's internationalisation process: An Australian perspective", International Journal of Operations \& Production Management, Vol. 35 No. 3, pp. 346-69.

Jensen, P.D.Ø. and Petersen, B. (2014), "Value creation logics and internationalization of service firms", International Marketing Review, Vol. 31 No. 6, pp. 557-75.

Johanson, J. and Vahlne, J.-E. (2009), "The Uppsala internationalization process model revisited: From liability of foreignness to liability of outsidership", Journal of International Business Studies, Vol. 40, pp. 1411-31.

Kerneis, P. (2018), "Professional Services", in Drake-Brockman, J. and Messerlin, P.A. (Eds.), Potential benefits of an Australia-EU free trade agreement: Key issues and options, University of Adelaide Press, Adelaide, Australia, pp. 245-57.

Konan, D.E. and Maskus, K.E. (2006), "Quantifying the Impact of Services Liberalization in a Developing Country", Journal of Development Economics, Vol. 81 No. 1, pp. 142-62. Kundu, S.K. and Lahiri, S. (2015), "Turning the Spotlight on Service Multinationals: New Theoretical Insights and Empirical Evidence", Journal of International Management, Vol. 21, pp. 215-19.

Markovic, N. (2012), Australia's Evolving Relationship with the European Union: An Update, Parliament of Australia: Department of Parliamentary Services, Canberra. Mattoo, A. (2003), "China's Accession to the WTO: The Services Dimension", Journal of International Economic Law, Vol. 6 No. 2, pp. 299-339.

Mehreen, H., Rammal, H.G., Pereira, V. and Del Giudice, M. (2021), "Investigating the influence of absorptive capacity of recipients within cross-border transfer of knowledge: evidence from emerging markets", International Marketing Review, Vol. Earlycite: 10.1108/IMR-11-2020-0264. 
Meyer, C., Skaggs, B., Nair, S. and Cohen, D. (2015), "Customer Interaction Uncertainty, Knowledge, and Service Firm Internationalization", Journal of International Management, Vol. 21 No. 3, pp. 249-59.

Nonaka, I. and Von Krogh, G. (2009), "Perspective-tacit knowledge and knowledge conversion: controversy and advancement in organizational knowledge creation theory", Organization Science, Vol. 20 No. 3, pp. 635-52.

Patel, P., Rammal, H.G., Ferreira, J.J. and Prikshat, V. (2021), "Knowledge management, sharing and transfer in cross-national teams and the remote management of team members: the onsite-offshore phenomenon of service EMNEs", Journal of Global Mobility: The Home of Expatriate Management Research, Vol. ahead-of-print. https://doi.org/10.1108/JGM-032021-0020.

Pla-Barber, J., Sanchez-Peinado, E. and Madhok, A. (2010), "Investment and Control Decisions in Foreign Markets: Evidence from Service Industries", British Journal of Management, Vol. 21, pp. 736-53.

Rafferty, M. and Ham, R. (2004), "The Global Race for FDI: The Case of Australian Investment in Europe", in Oxelheim, L. and Ghauri, P.N. (Eds.), European Union and the Race for Foreign Direct Investment in Europe, Elsevier, Oxford, pp. 209-35.

Rammal, H.G. and Rose, E.L. (2014), "New Perspectives on the Internationalization of Service Firms", International Marketing Review, Vol. 31 No. 6, pp. 550-56.

Ruiz-Pava, G. and Forero-Pineda, C. (2020), "Internal and external search strategies of innovative firms: the role of the target market", Journal of Knowledge Management, Vol. 24 No. 3, pp. 495-518.

Segal-Horn, S. and Dean, A. (2009), "Delivering 'effortless experience' across borders: Managing internal consistency in professional service firms", Journal of World Business, Vol. 44 No. 1, pp. 41-50.

Seymour, R.G. (2006), "Hermeneutic phenomenology and international entrepreneurship research", Journal of International Entrepreneurship, Vol. 4, pp. 137-55.

Silverman, D. (2000), Doing qualitative research: a practical handbook, Sage Publications, London.

Tillett, A. (2021), "These are the big winners from the British free trade deal", Australian Financial Review, Vol. 16 June.

Winters, L.A. (2018), "What Difference does Brexit Make? Potential Benefits of an Australia-EU Free Trade Agreement", in Drake-Brockman, J. and Messerlin, P.A. (Eds.), Potential benefits of an Australia-EU free trade agreement: Key issues and options, University of Adelaide Press, Adelaide, Australia, pp. 61-74.

World Bank. (2019), "World Development Indicators: Structure of output", available at: http://wdi.worldbank.org/table/4.2 (accessed 26 May 2021).

World Bank. (2020), "Trade in Services", available at: https://data.worldbank.org/indicator/BG.GSR.NFSV.GD.ZS (accessed 13 May 2021). WTO and the World Bank. (2018), "I-TIP Services: GATS", available at: http://itip.wto.org/services/default.aspx (accessed 12 July 2018).

Zhang, X., Zhong, W. and Makino, S. (2015), "Customer involvement and service firm internationalization performance: An integrative framework", Journal of International Business Studies, Vol. 46, pp. 355-80. 